\title{
ЛАЙМ-БОРЕЛІОЗ ТА КЛІЩОВІ ПОВОРОТНІ ГАРЯЧКИ У ЛІСІВНИКІВ ТЕРНОПІЛЬЩИНИ
}

\author{
${ }^{1}$ Тернопільський національний медичний університет імені І.Я. Горбачевського МОЗ України, \\ 2Лабораторія «IGeneX Inc.» (Мілпітас, Каліфрорнія, США)
}

Мета дослідження - 3'ясувати частоту інфрікування B. burgdorferi s. I. (збудниками Лайм-бореліозу) i B. hermsii ma B. miyamotoi (збудниками кліщових поворотних лихоманок) працівників лісових господарств Тернопільщини, використавши двохетапну схему діагностики (ІФА та імуноблот), встановити клінічні прояви поєднаного перебігу цих бореліозів.

Пацієнти і методи. Під спостереженням знаходилося 339 працівників 4 лісових (Бучацького, Кременецького, Тернопільського, Чортківського) і Бережанського лісомисливського господарств Тернопільської області. Обстежені мали вік від 20 до 65 років. Чоловіків було 330, жінок - 9. Антитіла до антигенів збудників комплексу B. burgdorferi s. I. у сироватці крові лісівників визначали методом імунофрерментного аналізу (IФA) з використанням тест-систем компанії Euroimmun AG (Німеччина). Зразки крові з проміжними й позитивними результатами першого етапу роботи досліджували методом імунного блотингу. Обстеження проводили в лабораторії Центру із вивчення Лаймбореліозу та інших інфрекцій, що передаються кліщами, який фрункціонує при Тернопільському національному медичному університеті імені І.Я. Горбачевського МОЗ України.

Для визначення антитіл до В. hermsii ma B. miyamotoi - збудників кліщових поворотних лихоманок методом імунного блотингу відібрали 114 сироваток крові лісівників, в яких були позитивні або проміжні результати детекції специфрічних IgM ma IgG до комплексу B. burgdorferi s. I в ІФА. Вони були віком від 20 до 65 років; чоловіків - 113, жінок - 1. Антитіла до збудників поворотних лихоманок у сироватці крові лісівників визначали науковці лабораторії «IGeneX Inc.» (Мілпітас, Каліфрорнія, США), використовуючи метод імунного блотингу.

Результати. Дослідження методом імуноблоту підтвердило наявність антитіл класів IgM i/чu IgG (позитивні або проміжні результати) до B. burgdorferi s. I. (B. burgdorferi s. s., B. afzelii ma B. garinii) y 85,1\% iз 114 працівників лісових господарств Тернопільщини. Вперше в лісівників Тернопілля методом імуноблотингу виявлено антитіла класів IgM i/чu IgG до збудників кліщових поворотних гарячок (B. hermsii ma B. miyamotoi) у $34,2 \%$ із 114 осіб, в яких попередньо в ELISA знайдено антитіла IgM i/чи IgG до B. burgdorferi s. I. Серед специфрічних IgG в обстежених осіб частіше відзначали антитіла до збудників Лайм-бореліозу - 78,1 проти 21,9 \%, коли їх не було ( $p<0,05)$, тоді як антитіла цього класу до збудників кліщових поворотних лихоманок відзначали значно рідше - 12,3 проти 85,9 \% відповідно $(p<0,05)$. Антитіл IgG до B. burgdorferi s. I. в обстежених осіб виявляли значно частіше, ніж антитіла цього класу до B. hermsii ma B. miyamotoi $(78,1$ проти 12,3 \%, р<0,05). Лісівники, в яких одночасно виявляли антитіла до збудників Лайм-бореліозу і кліщових поворотних лихоманок, відзначили раніший початок сезону нападів кліщів (березень-жовтень), у них частіше були прояви інтоксикаційного синдрому та ураження опорно-рухової системи, ніж в осіб, у котрих наявні лише антитіла до B. burgdorferi s. I.

Ключові слова: Лайм-бореліоз, кліщові поворотні лихоманки, діагностика, ІФА, імуноблот, анкетування, лісівники.

Borrelia складають гетерогенну популяцію мікроорганізмів - понад 30 різних видів, що передаються кліщами. Їх розділили на 2 групи: 1-ша - комплекс Borrelia burgdorferi sensu lato (s. I.) (у широкому розумінні), що спричинюють Лайм-бореліоз; 2-га - збудники кліщових поворотних гарячок [1-3]. У групу збудників Лаймбореліозу входять B. burgdorferi sensu stricto (s. s.) (у вузькому розумінні), B. garinii, B. afzelii, B. lusitaniae, B. valaisiana та інші, яких об'єднує фенотипічна подібність. Цих бактерій виявляють у країнах з помірно-континентальним кліматом північної півкулі, вони переносяться іксодовими кліщами [4-6].

У групу збудників кліщових поворотних лихоманок (англ. Tick-borne relapsing fever (TBRF), tick fever, кліщо- 
ва та вошина) зачислені В. duttoni, B. hermsii, B. parkerii, B. turicatae, B. miyamotoi. Ці бактерії зустрічаються в зоні тропічного та субтропічного клімату, переносяться кліщами роду Ornithodoros (кліщові поворотні лихоманки) або Pediculus vestimenti - платяними вошами (вошивий поворотний тиф). Окрім того, B. miyamotoi можуть передаватися тими ж твердими кліщами роду Іксоди, які переносять B. burgdorferi s. I. [7, 8]. За даними літератури, збудниками поворотних кліщових лихоманок в Європі та Азії є Borrelia hispanica [9], B. persica [10] та B. miyamotoi [11].

Метою роботи було з'ясувати поширеність інфрікування бореліями, збудниками Лайм-бореліозу та кліщових поворотних лихоманок, працівників лісових господарств Тернопільської області, а також встановити клінічні прояви при поєднаному перебігу цих бореліозів. Дослідження розпочато восени 2015 р., закінчено восени 2016 р. Його проводили працівники кафедри інфекційних хвороб з епідеміологією, шкірними та венеричними хворобами та інших підрозділів ТНМУ імені І.Я. Горбачевського спільно з працівниками лабораторії «IGeneX Inc.» (Мілпітас, Каліфорнія, США).

\section{Пацієнти і методи}

Під спостереженням знаходилося 339 працівників 4 лісових (Бучацького, Кременецького, Тернопільського, Чортківського) і Бережанського лісомисливського господарств Тернопільської області. У цю групу увійшли майстри лісу, лісоруби, водії, трактористи, звальщики лісу, лісничі, помічники лісничих, слюсарі, робітники, механіки, автоелектрики, станочники, працівники адміністрації господарств. Обстежені мали вік від 20 до 65 років. Чоловіків було 330, жінок - 9 .

Серологічну діагностику Лайм-бореліозу проводили в лабораторії Центру із вивчення Лайм-бореліозу та інших інсекцій, що передаються кліщами, який фрункціонує при Тернопільському національному медичному університеті імені І.Я. Горбачевського МОЗ України. Антитіла до антигенів збудників комплексу B. burgdorferi s. I. у сироватці крові визначали методом імуноферментного аналізу (ІФА) з використанням тест-систем компанії Euroimmun AG (Hiмеччина): антитіла класу М - тест-системою Anti-Borrelia burgdorferi ELISA (IgM), класу G - Anti-Borrelia plus VISE ELISA (IgG). Відповідно до рекомендацій виробника, результат $\geq 22 \mathrm{RU} / \mathrm{ml}$ вважали позитивним, від 16 до $22 \mathrm{RU} /$ $\mathrm{ml}$ - проміжним, $\leq 16 \mathrm{RU} / \mathrm{ml}$ - негативним.

Антитіла одного і/чи обох класів - IgM і/чи $\operatorname{lgG}$ до B. burgdorferi s. I. (B. burgdorferi s. S., B. afzelii ma B. garinii) (позитивні або проміжні результати) виявлено у 146 (43,1%) працівників лісових господарств Тернопільської області [12].

Для визначення антитіл до B. hermsii та B. miyamotoi - збудників кліщових поворотних лихоманок методом імун- ного блотингу відібрали 114 сироваток крові лісівників (через обмежену кількість тест-систем), в яких були позитивні або проміжні результати детекції специфічних $\lg \mathrm{M}$ і IgG до комплексу B. burgdorferi s. І. в ІФА. В імуноблоті для виявлення антитіл класу М використовували тест-системи Anti-Borrelia EUROLINE-WB (IgM), антитіл класу G - AntiBorrelia EUROLINE-WB (IgG). Отримані результати оцінювали за допомогою програмного забезпечення EURO Line Scan. Антитіла до збудників поворотних лихоманок у сироватці крові лісівників визначали науковці лабораторії «IGeneX Inc.» (Мілпітас, Каліфорнія, США), використовуючи метод імунного блотингу [13]. Інтерпретацію отриманих результатів проводили згідно з рекомендаціями виробника тест-систем [14].

У групу обстежених методом імунного блотингу ввійшли представники зазначених вище професій. Вони були віком від 20 до 65 років; чоловіків - 113, жінка - 1. Усі дали відповіді на питання уніфікованої міжнародної анкети-опитувальника, в якій відзначали кількість і місця укусів кліщів, описували способи їх видалення та скарги, які турбували їх після укусів.

\section{Результати досліджень та їх обговорення}

Серед обстежених 114 працівників лісу, сироватки яких досліджені методом імуноблотингу, 41 (35,9%) відмітили понад 3 епізоди нападів кліщів протягом професійної роботи, 1 напад мали 25 (21,9 \%), 2 - 20 $(17,5 \%)$ респондентів. 28 (24,7 \%) осіб не пам'ятали фракту присмоктування кліща протягом життя (табл. 1).

Найчастішими місцями присмоктування кліщів пацієнти відзначили живіт (47; 41,2 \%), ноги (33; 28,9 \%) і тулуб спереду (29; 25,4 \%). Напади в ділянки рук, тулуба ззаду та шиї згадувалися значно рідше - 15 (13,2 \%), 8 (7,1 \%) і 7 (6,1 \%) випадків відповідно. Присмоктування в голову відзначила лише 1 особа.

щодо способу видалення кліща, то найбільша кількість опитаних виривала його пальцями (50; 43,9 \%). 33 $(28,9 \%)$ особи продезінфрікували місце укусу дезрозчином, 26 (22,8 \%) - перед видаленням кліща змазували його олією. На жаль, допомогою лікаря чи медичної сестри для видалення кліща скористались лише 5 $(4,4 \%)$ осіб (табл. 1).

При аналізі результатів серологічного дослідження сироваток крові лісівників за допомогою ІФА на наявність специфічних IgM i IgG до комплексу B. burgdorferi s. I. встановлено, що позитивні результати щодо IgM були у 28 (24,6 \%) обстежених, проміжні - у 12 (10,5 \%), негативні - у 74 (64,9 \%). Водночас позитивні результати наявності специфічних антитіл класу IgG знайдено у $86(75,4 \%)$ осіб, проміжні - у 16 (14,1\%), негативні у $12(10,5 \%)$ (мал. 1). 
Таблиця 1

Характеристика нападів кліщів на обстежених лісівників і способи їх видалення

\begin{tabular}{|c|c|c|c|}
\hline \multicolumn{2}{|c|}{ Укуси кліщів та спосіб їх видалення } & $\mathrm{n}=114$ & $\%$ \\
\hline \multirow{4}{*}{ 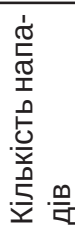 } & 1 & 25 & 21,9 \\
\hline & 2 & 20 & 17,5 \\
\hline & Багато (понад 3) & 41 & 35,9 \\
\hline & $\begin{array}{l}\text { Не мали жодного або не } \\
\text { пам'ятають }\end{array}$ & 28 & 24,7 \\
\hline \multirow{7}{*}{ 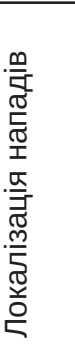 } & Руки & 15 & 13,2 \\
\hline & Ноги & 33 & 28,9 \\
\hline & \multirow{2}{*}{$\begin{array}{l}\text { Тулуб спереду } \\
\text { ззаду }\end{array}$} & 29 & 25,4 \\
\hline & & 8 & 7,1 \\
\hline & Голова & 1 & 0,9 \\
\hline & Шия & 7 & 6,1 \\
\hline & Живіт & 47 & 41,2 \\
\hline \multirow{10}{*}{ 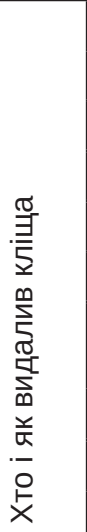 } & Лікар & 5 & 4,4 \\
\hline & Інша особа & 3 & 2,6 \\
\hline & Вирвав пальцями & 50 & 43,9 \\
\hline & Простими рухами & 8 & 7,1 \\
\hline & Викрутив & 5 & 4,4 \\
\hline & Зішкрябав нігтем & 7 & 6,1 \\
\hline & $\begin{array}{l}\text { Полив дезінфікувальним роз- } \\
\text { чином }\end{array}$ & 6 & 5,3 \\
\hline & Намазав олією & 26 & 22,8 \\
\hline & Продезінфрікував місце укусу & 33 & 28,9 \\
\hline & Інше & 4 & 3,5 \\
\hline
\end{tabular}

За даними літератури, відсоток позитивних результатів виявлення IgG до B. burgdorferi s. I. у країнах $€_{\mathrm{B}-}$ ропи різний: у Німеччині - 30,6 \%, у Швеції - 35,0 \%, в Італії - 24,3 \%. У Словакії ці антитіла були знайдені у 29,2 \% працівників лісу [15], в Італії - у 24,3 \% [16]. Отримані нами результати знаходження імуноглобулінів класу $\operatorname{lgM~у~працівників~лісових~господарств~співзвучні~}$ 3 даними науковців Польщі, в яких специфічні IgM виявлено у 15,6 \% лісівників, проміжні - у 7,8 \% [17].

Сироватки крові лісівників, в яких наявні позитивні та проміжні результати виявлення антитіл до комплексу B. burgdorferi s. I. в тесті ELISA, у подальшому досліджували методом імуноблоту. Позитивні результати стосовно специорічних IgM отримано в 13 (11,4\%), проміжні - у 10 (8,8 \%) обстежених. Також у сироватках крові визначали вміст специфічних IgG. Позитивні результати отримано у 89 (78,1 \%) працівників лісових господарств Тернопільщини, негативні - у 25 (21,9\%), проміжних результатів не було у жодного з обстежених (мал. 2).
Одночасно сироватки крові зазначених вище 114 лісівників з Тернопільщини досліджено методом імунного блотингу на наявність антитіл до збудників кліщових поворотних лихоманок - B. hermsii та B. miyamotoi в лабораторії «IGeneX Inc.» (Мілпітас, Каліфрорнія, США).

У результаті проведеного аналізу показників дослідження сироваток крові лісівників на наявність специфрічних $\lg$ M i lgG до зазначених вище збудників методом імуноблоту встановлено: позитивні або проміжні результати виявлення антитіл хоча б одного класу були у 39 (34,2 \%) обстежених, у тому числі антитіла класу IgM - у 29 (25,4 \%), IgG - у $16(14,1 \%)(p<0,05)$, обох класів одночасно (результат позитивний/позитивний і проміжний/проміжний) - у 5 (4,4%) (табл. 2).

Таблиця 2

Результати дослідження імунним блотом сироваток крові лісівників на наявність антитіл класів IgM і IgG до В. hermsii та B. miyamotoi $(\mathrm{n}=114), \%$

\begin{tabular}{|c|l|l|c|c|}
\hline \multirow{2}{*}{$\begin{array}{c}\text { № } \\
\text { пा }\end{array}$} & \multicolumn{2}{|c|}{ Класи антитіл і результати } & \multirow{2}{*}{$\mathrm{n}$} & \multirow{2}{*}{ IgM } \\
\cline { 2 - 3 } & \multicolumn{1}{|c|}{$\lg$} & \multicolumn{1}{c|}{ IgG } & \\
\hline 2 & Позитивний & Позитивний & 5 & 4,4 \\
\hline 3 & Позитивний & Негативний & 15 & 13,2 \\
\hline 4 & Позитивний & Проміжний & - & - \\
\hline 5 & Проміжний & Проміжний & - & - \\
\hline 6 & Негативний & Позитивний & 8 & 7,0 \\
\hline 7 & Проміжний & Негативний & 8 & 7,0 \\
\hline 8 & Негативний & Проміжний & 2 & 1,9 \\
\hline 9 & Негативний & Негативний & 75 & 65,8 \\
\hline Разом & & 114 & 100,0 \\
\hline
\end{tabular}

Зокрема, в імуноблоті науковцями зі США позитивні результати наявності IgM до B. hermsii та B. miyamotoi отримано у 20 (17,5 \%), проміжні - у 9 (7,9 \%) обстежених. Позитивні результати виявлення антитіл класу IgG були у 14 (12,3 \%), проміжні - у 2 (1,8 \%) обстежених лісівників (мал. 3).

Відсоток позитивних результатів наявності антитіл класу IgМ до збудників Лайм-бореліозу (B. burgdorferi s. I.) та кліщових поворотних лихоманок (B. hermsii та B. miyamotoi) у сироватці крові 114 працівників лісових господарств був приблизно однаковим. Серед специфічних IgG відсоток позитивних результатів наявності антитіл до збудників Лайм-бореліозу був значно вищим, ніж негативних - 78,1 проти 21,9 \% відповідно ( $<<0,05)$, тоді як до збудників кліщових поворотних лихоманок суттєво більше було негативних результатів - 85,9 проти 12,3\% (p<0,05). Окрім того, відсоток осіб, в яких 
отримано позитивні результати пошуку антитіл класу IgG до B. burgdorferi s. I., достовірно вищий ніж тих, у кого були антитіла до B. hermsii та B. miyamotoi - 78,1 проти 12,3\% (р<0,05) (мал. 3).

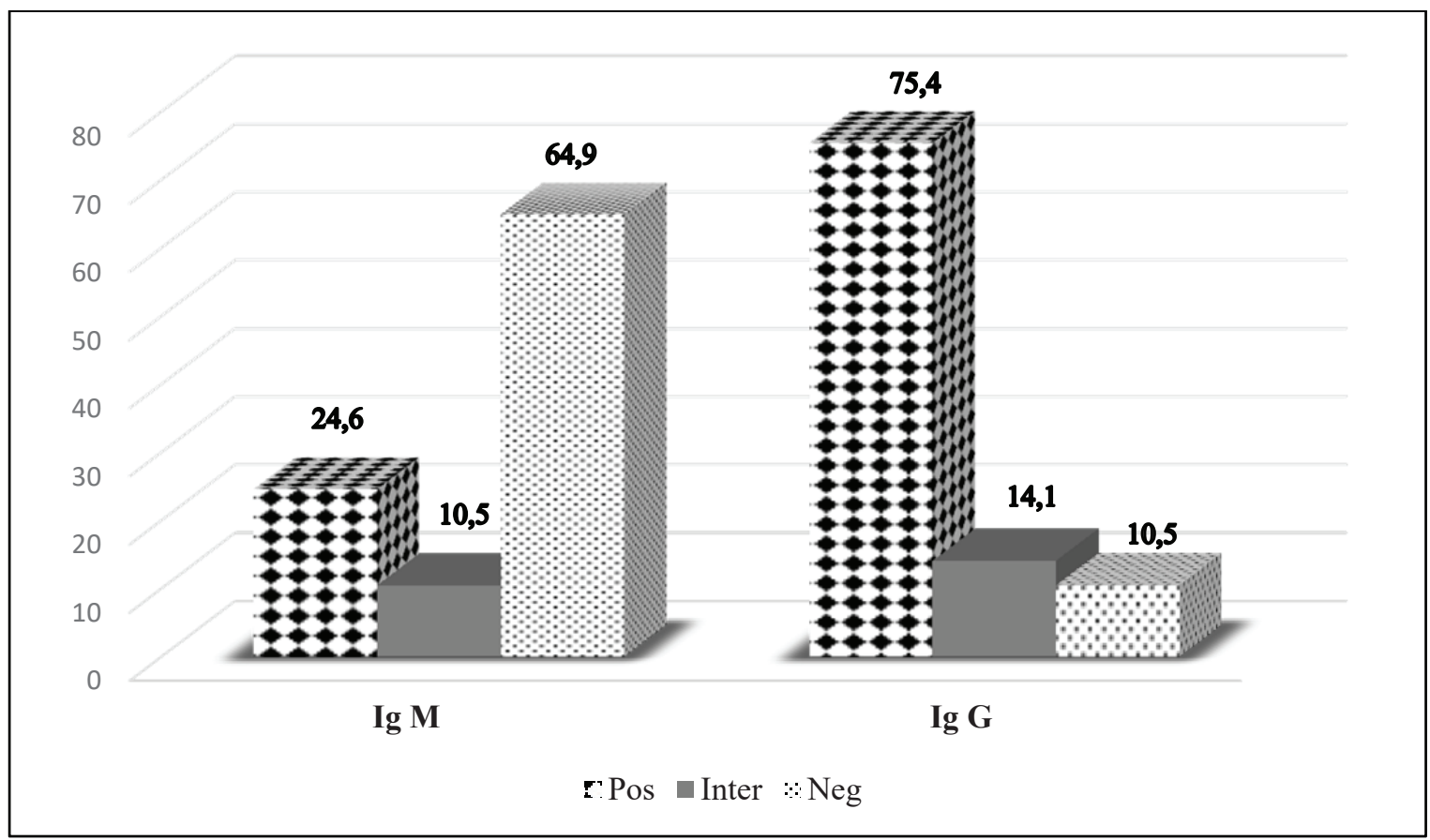

Мал. 1. Результати дослідження сироваток крові лісівників за допомогою ІФА щодо наявності антитіл класів IgM та IgG до В. burgdorferi s. I. ( $\mathrm{n}=114)$, \%.

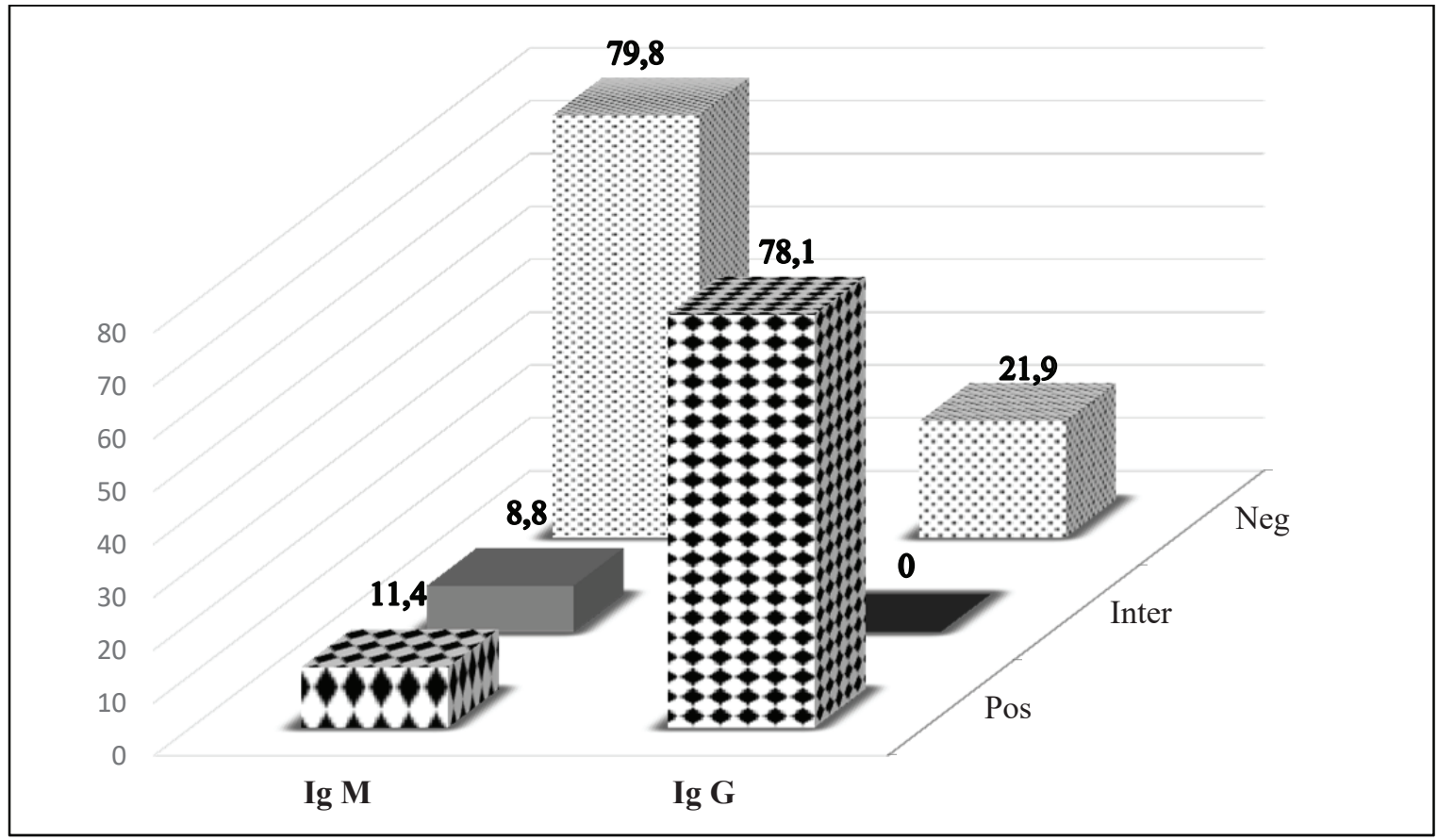

Мал. 2. Результати дослідження сироваток крові лісівників методом імунного блоту на наявність антитіл класів IgM та IgG до В. burgdorferi s. I. ( $\mathrm{n}=114), \%$. 


\section{ОРИГІНАЛЬНІ ДОСЛІДЖЕННЯ}

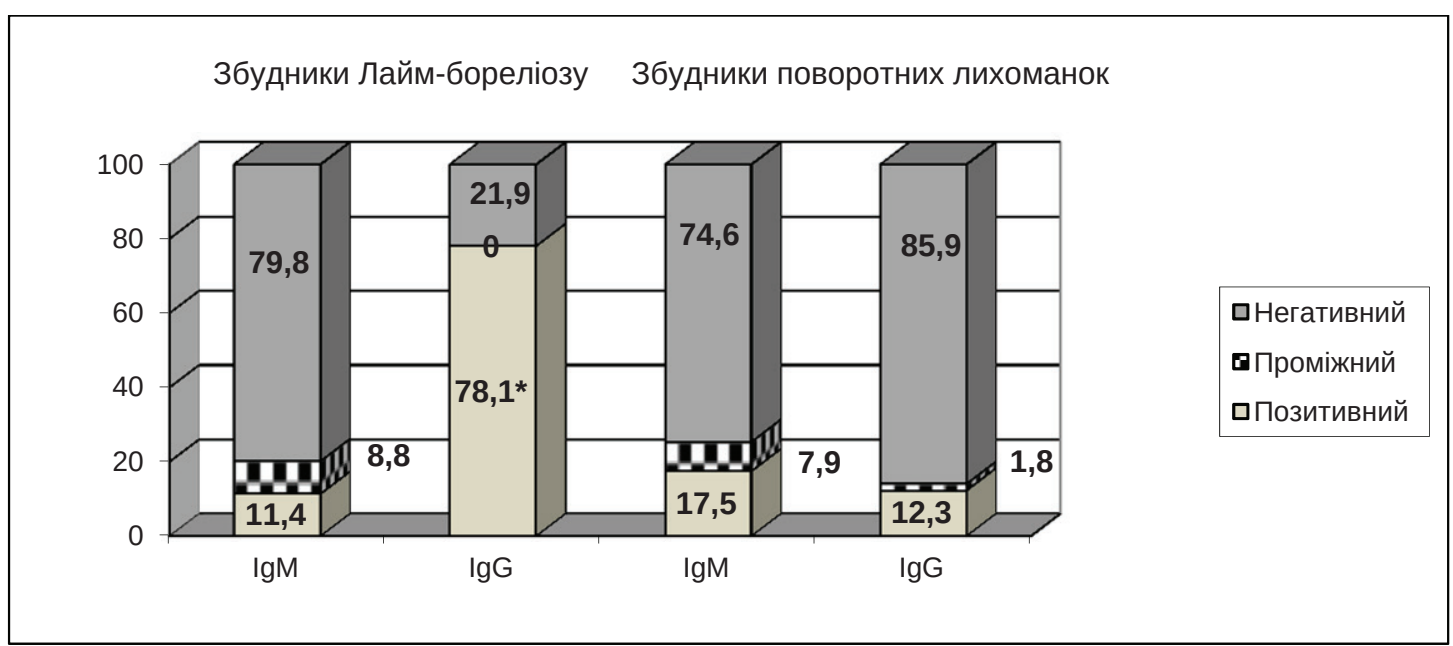

Мал. 3. Результати дослідження сироваток крові лісівників методом імунного блоту на наявність антитіл класів IgM i IgG до B. burgdorferi s. I. та B. hermsii та B. miуamotoi (поворотні лихоманки) (n=114), \%.

Примітка: * - різниця достовірна щодо показника відповідних антитіл при Лайм-бореліозі, p<0,05.

Залежно від отриманих результатів дослідження сироваток крові 114 лісівників методом імунного блотингу на наявність антитіл до збудників Лайм-бореліозу і кліщових поворотних лихоманок, усіх обстежених поділили на дві групи. У 1-шу групу ввійшли 39 працівників лісових господарств, у сироватках крові яких одночасно знайдено антитіла до B. burgdorferi s. I. (збудників Лаймбореліозу) та В. hermsii і B. miyamotoi (збудників кліщових поворотних лихоманок); у 2-гу - 75 осіб, в яких виявлено лише антитіла до B. burgdorferi s. I.
Далі з'ясовували, коли лісівники обох груп найчастіше зазнавали нападів кліщів. Місяці укусів кліщів змогли вказати лише 55 лісівників із 114 обстежених, у тому числі 28 осіб з 1-ої групи і 33 - 3 2-ої.

Встановлено, що напади кліщів у лісівників Тернопільщини протягом 2015-2016 рр. реєстрували з березня по листопад. В обстежених лісівників обох груп відзначено два піки - y V та VII місяцях. Слід зазначити, що лише лісівники 1-ої групи зазнали нападів кліщів уже в березні, тоді як в листопаді укуси кліщів реєстрували лише респонденти 2-ої (мал. 4).

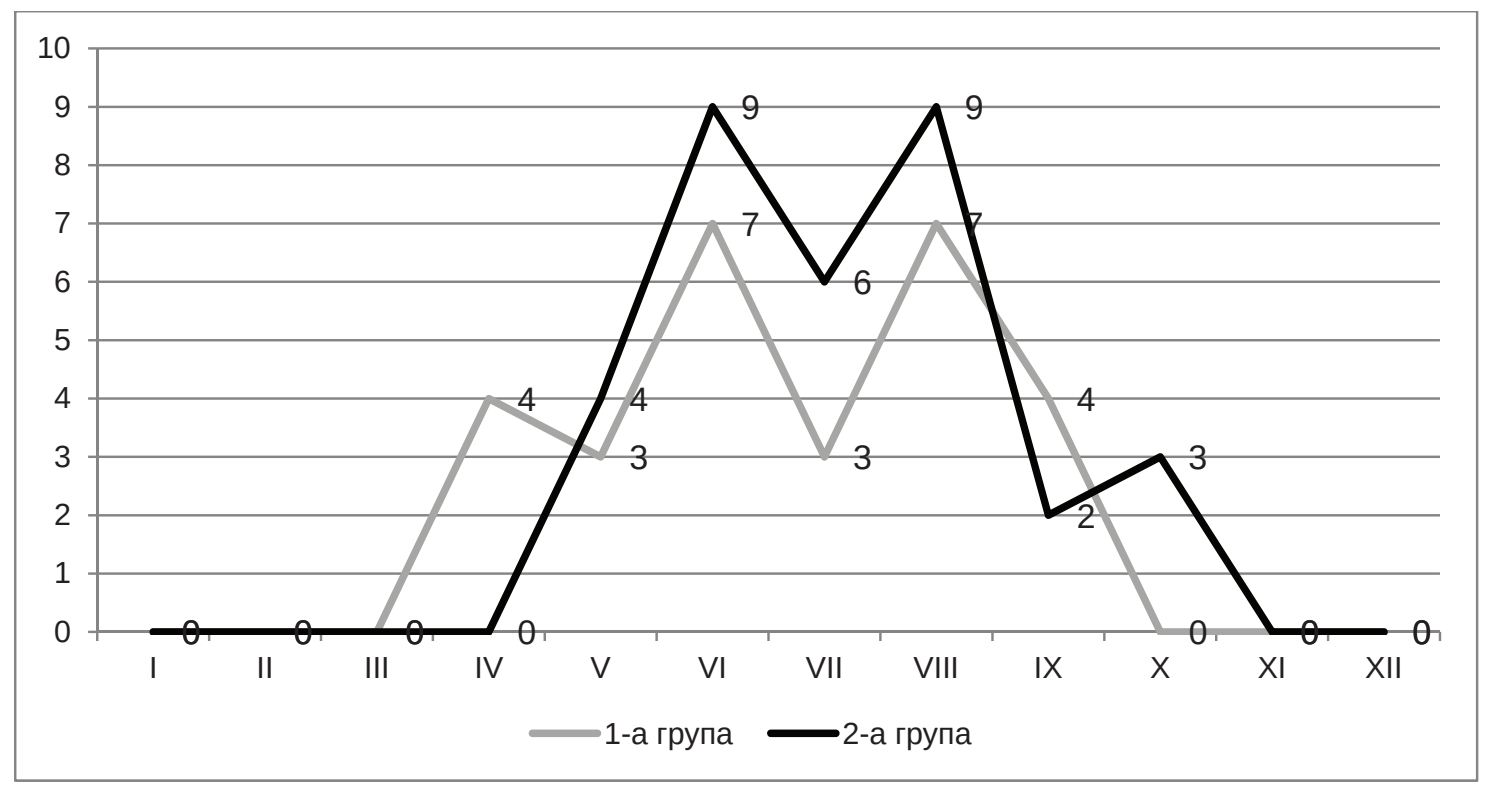

Мал. 4. Число нападів кліщів на лісівників 1-ої (n=28) та 2-ої (n= 33) груп у різні місяці протягом 2015-2016 рр. 
Проведено аналіз скарг лісівників обох груп. Усі скарги поділено на декілька груп: інтоксикаційний синдром (підвищення температури тіла, загальна слабість, біль голови, реґіонарний лімсраденіт); ураження опорнорухової системи (ОРС; артралгії та міалгії); ураження серцево-судинної системи (ССС; неприємні відчуття в ділянці серця, аритмія, підвищення артеріального тиску); ураження нервової системи (НС; відчуття оніміння, слабість і відчуття розпирання в руках і ногах).

Встановлено, що прояви інтоксикаційного синдрому відзначено в 63,4 \% лісівників 1-ої групи проти 20,3 \% - другої $(p<0,05)$. Респонденти цієї ж групи суттєво частіше вказували на наявність симптомів ураження опорно-рухової системи (мал. 5).

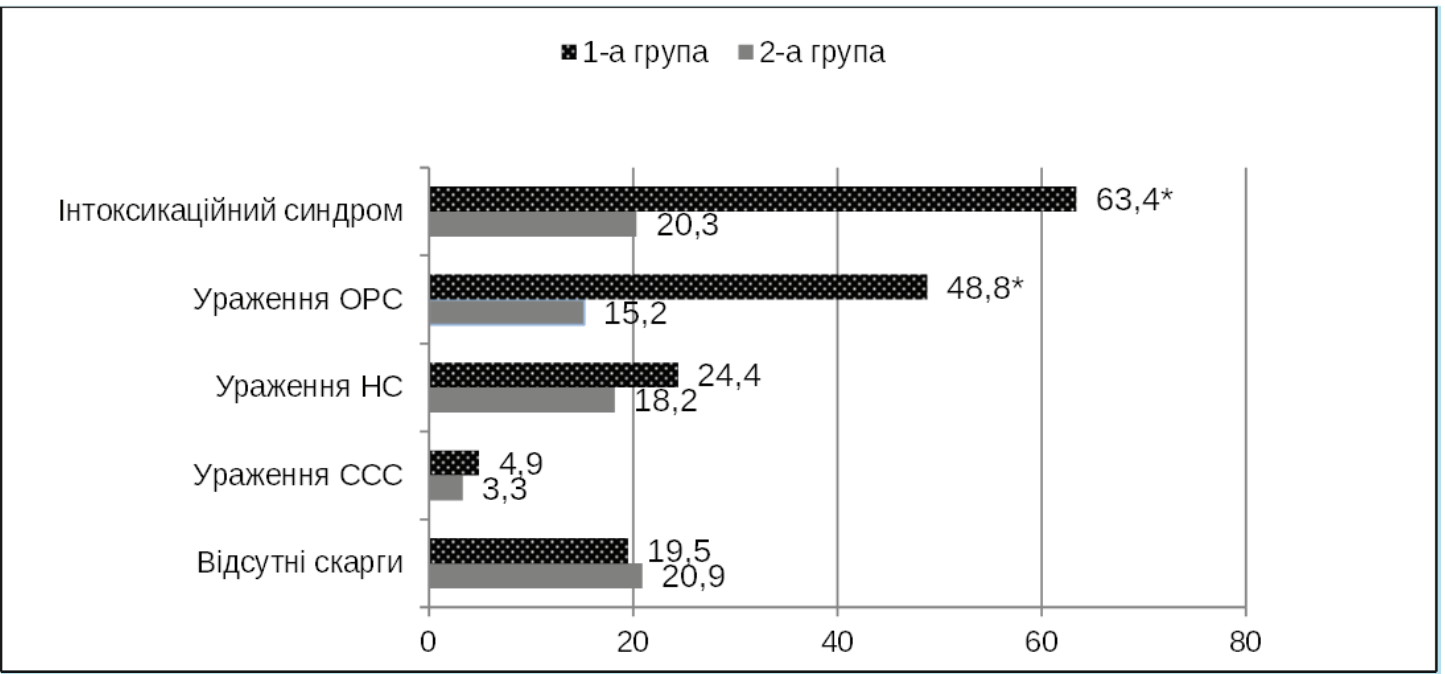

Мал. 5. Частота виявлення скарг з боку різних органів і систем у лісівників 1-ої (n=39) і 2-ої груп ( $\mathrm{n=75),} \mathrm{\% .}$ Примітка: * - різниця достовірна між групами $(p<0,05)$.

Отримані нами дані щодо клінічних проявів Лаймбореліозу та кліщових поворотних лихоманок, близькі до результатів досліджень науковців Словенії, Бельгії та Польщі [15-17].

\section{Висновки}

1. Метод імунного блоту дозволив підтвердити наявність антитіл класів IgM і/чи IgG (позитивні або проміжні результати) до B. burgdorferi s. I. (B. burgdorferi s. s., B. afzelii ma B. garinii) у 85,1 \% із 114 лісівників Тернопільщини, в яких попередньо були виявлені антитіла до борелій в ІФА (ELISA) (позитивні і проміжні показники).

2. Вперше на Тернопільщині методом імуноблотингу виявлено антитіла класів IgM i/чи IgG до збудників кліщових поворотних гарячок (B. hermsii та B. miyamotoi) у $34,2 \%$ із 114 лісівників, в яких попередньо в ELISA знайдено антитіла IgM i/чи IgG до B. burgdorferi s. I. (позитивні або проміжні результати).

3. Серед специфічних IgG в обстежених осіб частіше відзначали наявність антитіл до збудників Лайм- бореліозу - 78,1 проти 21,9 \%, коли їх не було ( $<<0,05)$, тоді як антитіла цього класу до збудників кліщових поворотних лихоманок відзначали значно рідше - 12,3 проти 85,9 \% відповідно ( $p<0,05)$.

4. Антитіл класу IgG до B. burgdorferi s. І. в обстежених осіб виявляли значно частіше, ніж антитіла цього класу до B. hermsii та B. miyamotoi (78,1 проти 12,3 \%, $\mathrm{p}<0,05)$.

5. Працівники лісових господарств Тернопільської області, в яких знайдені антитіла до збудників кліщових поворотних лихоманок, відзначали напади кліщів з березня по жовтень, тоді як лісівники, в яких виявляли лише антитіла до B. burgdorferi s. І., з квітня по листопад.

6. Лісівники Тернопільщини, в яких одночасно виявляли антитіла до збудників Лайм-бореліозу і кліщових поворотних лихоманок, суттєво частіше відзначали прояви інтоксикаційного синдрому та ураження опорнорухової системи, ніж особи, у котрих були наявні лише антитіла до B. burgdorferi s. I. 


\section{Література}

1. Adeolu M. A phylogenomic and molecular marker based proposal for the division of the genus Borrelia into two genera: the emended genus Borrelia containing only the members of the relapsing fever Borrelia, and the genus Borreliella gen. nov. containing the members of the Lyme disease Borrelia (Borrelia burgdorferi sensu lato complex) / M. Adeolu, R.S. Gupta // Antonie Van Leeuwenhoek. - 2014. - Vol. 105. - P. 1049-1072.

2. Oren A. Notification of changes in taxonomic opinion previously published outside the IJSEM. Int. J. Syst / A. Oren, G. M. Garrity // Evol. Microbiol. - 2015. - Vol. 65. - P. 7-10.

3. “Genus II. Borrelia Swellengrebel 1907, 582AL,"in Bergey's Manual of Systematic Bacteriology, eds D. J. Brenner, N. R. Krieg, G. M. Garrity, J. T. Staley. - 2011. - N 3, 2nd Edn. (New York, NY: Springer). - P. 484-498.

4. Сарксян Д.С. Дифрференциальная диагностика иксодового клещевого боррелиоза, вызванного Borrelia miyamotoi / Д.С. Сарксян, В.В. Малеев, А.Е. Платонов // Инфекционные болезни. - 2012. №10 (4). - С. 41-44.

5. Лайм-бореліоз. Діагностичні критерії, лікування і профрілактика: метод. рекомендації / [уклад.: М.А. Андрейчин, В.С. Копча, М.І. Шкільна та ін.]. - Тернопіль: ТДМУ, 2019. - 52 с.

6. Попович О.О. Лайм-бореліоз: сучасна проблема інфектології (клінічна лекція) / О.О. Попович // Актуальна інфректологія. - 2016. - №3 (12). - С. 114-122.

7. Centers for Disease Control and Prevention. Tick-Borne Relapsing Fever (TBRF). - 2015. - Access mode : https://www.cdc. gov/relapsing-fever/index.html (accessed on 23 August 2018).

8. Centers for Disease Control and Prevention. Borrelia Miyamotoi. - 2019. - Access mode : https://www.cdc. gov/ticks/ miyamotoi.html. (accessed on 20 June 2019).

9. Borrelia hispanica in Ornithodoros erraticus, Portugal / M. Palma, I. Lopes de Carvalho, M. Figueiredo [et al.] // Clin. Microbiol. Infect. - 2012. - N 18. - P. 696-701.

\section{References}

1. Adeolu, M., \& Gupta, R.S. (2014). A phylogenomic and molecular marker based proposal for the division of the genus Borrelia into two genera: the emended genus Borrelia containing only the members of the relapsing fever Borrelia, and the genus Borreliella gen. nov. containing the members of the Lyme disease Borrelia (Borrelia burgdorferi sensu lato complex). Antonie Van Leeuwenhoek, 105, 1049-1072.

2. Oren, A., \& Garrity, G.M. (2015). Notification of changes in taxonomic opinion previously published outside the IJSEM. Evol. Microbiol, 65, 7-10.

3. Wang, G., \& Schwartz, I. (2011). Genus II. Borrelia Swellengrebel 1907, 582AL,"in Bergey's Manual of Systematic Bacteriology. Brenner, D.J., Krieg, N.R., Garrity, G.M., Staley, J.T. (Eds.). New York, NY: Springer, 484-498.

4. Sarksyan, D.S., Maleev, V.V., Platonov, A.E., Platonova, O.V., Karn, L.S. (2012). Differential diagnosis of ixodic tick-borne borreliosis caused by Borrelia miyamotoi. Infektsionnye bolezni -Infectious Diseases, 10 (4), 41-44 [in Russian].

5. Andreychyn, M.A., Kopcha, V.S., Shkilna, M.I., Korda, M.M., Klishch, I.M., Nykytiuk, S.O., ... Nychyk N.A. (2019). Lyme borreliosis. Diagnostic criteria, treatment and prevention: Method. Recommendations. Ternopil [in Ukrainian].
10. Elbir H. Genome sequence of the Asiatic species Borrelia persica / H. Elbir, P. Larsson, J. Normark [et al.] // Genome Announc. - 2014. - Vol. 2. - P. 1127-1140.

11. Borrelia miyamotoi infection in nature and in humans / P. J. Krause, D. Fish, S. Narasimhan, A. G. Barbour // Clin. Microbiol. Infect. - 2015 - Vol. 21. - P. 631-639.

12. Шкільна М.І. Лайм-бореліоз у працівників лісових господарств Тернопільської області / М.І. Шкільна // Інфекційні хвороби. - 2016. - № 1(83). - С. 36-40.

13. Line immunoblot assay for tick-borne relapsing fever and findings in patient sera from Australia, Ukraine, and the USA / J. S. Shah, S. Liu, I. Du Cruz [et al.] // Healthcare. - 2019. - Vol. 7 (4). - P. 121

14. Pilot study of immunoblots with recombinant Borrelia burgdorferi antigens for laboratory diagnosis of Lyme disease / S. Liu, I. Du Cruz, C. Calalo-Ramos [et al.] // Healthcare. - 2018. - Vol. 6 (3). -P. 99.

15. Sero-epidemiological study of Lyme disease among highrisk population groups in eastern Slovakia / L'. Zákutná, E. Dorko, E. Mattová, K. Rimárová // Ann. Agric. Environ. Med. -2015. - Vol. 22. - P. 632-636.

16. De Keukeleire M. Seroprevalence of Borrelia burgdorferi in Belgian forestry workers and associated risk factors / M. De Keukeleire, A. Robert, V. Luyasu, B. Kabamba, S. O. Vanwambeke // Parasites \& Vectors. - 2018. - Vol. 11 (277). - P. 22.

17. PańczukA. Exposure to ticks and seroprevalence of Borrelia burgdorferi among a healthy young population living in the area of southern Podlasie / Pańczuk A., Kozioł-Montewka M., TokarskaRodak M. // Annals of Agricultural and Environmental Medicine. - 2014 - Vol. 21 (3). - P. 512-517.

6. Popovich, O.O. (2016). Lyme borreliosis: a modern problem of infectology (clinical lecture). Aktualna infektolohiia - Actual Infectology, 3 (12), 114-122 [in Ukrainian].

7. 7. Centers for Disease Control and Prevention. (2015). TickBorne Relapsing Fever (TBRF). www.cdc.gov. Retrieved from: https:// www.cdc.gov/relapsing-fever/index.html (accessed on 23 August 2018).

8. Centers for Disease Control and Prevention. (2019). Borrelia Miyamotoi. www.cdc.gov. Retrieved from: https://www.cdc.gov/ticks/ miyamotoi.html. (accessed on 20 June 2019).

9. Palma, M., Lopes de Carvalho, I., Figueiredo, M., Amaro, F., Boinas, F., \& Cutler, S.J. (2012). Borrelia hispanica in Ornithodoros erraticus, Portugal. Clin. Microbiol. Infect., 18, 696-701.

10. Elbir, H., Larsson, P., Normark, J., Upreti, M., Korenberg, E., \& Larsson, C. (2014). Genome sequence of the Asiatic species Borrelia persica. Genome Announc., 2, 1127-1140.

11. Krause, P.J., Fish D., Narasimhan, S., \& Barbour, A.G. (2015). Borrelia miyamotoi infection in nature and in humans. Clin. Microbiol. Infect, 21, 631-639.

12. Shkilna, M.I. (2016). Lyme borreliosis in forestry workers of Ternopil region. Infektsiini khvoroby - Infectious Diseases, 1 (83), 36-40 [in Ukrainian]. 
13. Shah, J.S., Liu, S., Du Cruz, I., Poruri, A., Maynard, R., Shkilna, M. (2019). Line immunoblot assay for tick-borne relapsing fever and findings in patient sera from Australia, Ukraine, and the USA. Healthcare, 7 (4), 121.

14. Liu, S., Du Cruz, I., Calalo Ramos, C., Taleon, P., Ramasamy, R., \& Shah, J. (2018). Pilot study of immunoblots with recombinant Borrelia burgdorferi antigens for laboratory diagnosis of Lyme disease. Healthcare, 6 (3), 99.

15. Zákutná, L'., Dorko, E., Mattová, E., \& Rimárová, K. (2015). Sero-epidemiological study of Lyme disease among high-risk population groups in eastern Slovakia. Ann. Agric. Environ. Med., 22, 632-636.

16. De Keukeleire, M., Robert, A., Luyasu, V., Kabamba, B., \& Vanwambeke, S.O. (2018). Seroprevalence of Borrelia burgdorferi in Belgian forestry workers and associated risk factors. Parasites \& Vectors, 11, 277.

17. Pańczuk, A., Kozioł-Montewka, M., Tokarska-Rodak, M. (2014). Exposure to ticks and seroprevalence of Borrelia burgdorferi among a healthy young population living in the area of southern Podlasie. Annals of Agricultural and Environmental Medicine, 21 (3), 512-517.

\section{LYME BORRELIOSIS AND TICK-BORNE RELAPSING FEVER IN FORESTERS OF TERNOPIL REGION}

M.I. Shkilna ${ }^{1}$, J.S. Shah ${ }^{2}$, M.A. Andreychyn ${ }^{1}$, I.D. Cruz ${ }^{2}$, O.L. Ivakhiv ${ }^{1}$, M.M. Korda ${ }^{1}$, I.M Klishch ${ }^{1}$, S.Y. Zaporozhan ${ }^{1}$

${ }^{1}$ I. Horbachevsky Ternopil National Medical University, ${ }^{2}$ GGeneX Inc. Laboratory (Milpitas, CA, USA)

SUMMARY. The aim of the study - to determine the case incidence of $B$. burgdorferi s. I. (the agent of Lyme Borreliosis) and B. hermsii ma B. miyamotoi (the agents of tick-borne relapsing fever) infection among foresters of the Ternopil region and study the clinical manifestation of combined dual infection using of two-step diagnostic scheme (ELISA and immunoblotting).

Patients and Methods. 339 foresters were involved in the study in the Ternopil region: 4 forestries (Buchah, Krementz, Ternopil, and Chortkiv districts) and Berezhany's forestry and hunting grounds. The age of patients was from 20 to 65 years old. There were 330 males and 9 females. Antibodies to $B$. burgdorferi s. I. antigens were detected by Euroimmun AG assay (Germany). Serum samples with positive and borderline results were confirmed by immunoblot (EUROLINE Borrelia RNAT). All tests were done in the Center of Study of Lyme borreliosis and other infectious diseases transmitted by ticks at I. Horbachevsky Ternopil National Medical University.

For detection of antibodies to B. hermsii ma B. miyamotoi - the cause of tick-borne relapsing fever, we use 114 human blood samples of forestry workers, which were positive or borderline to B. burgdorferi s. L IgM and IgG antibodies in the ELISA test. The average age of involved persons was from 20 to 65 years old, among them 113 males and 1 female. Samples were examined in the laboratory IGeneX Inc. (Milpitas, CA, USA) by immune blotting.
Results. Immunoblot examination confirmed the presence of B. burgdorferi s. I (B. burgdorferi s. S., B. afzelii and $B$. garinii) IgM and/or IgG antibodies (positive or borderline results) in $85.1 \%$ of 114 forestry workers of Ternopil region. The first time, IgM and/or IgG antibodies to agents of tick-borne relapsing fever (B. hermsii ma B. miyamotoi) were detected by immunoblot in $34.2 \%$ of 114 forestry workers of Ternopil regions, among those samples which were founded previously positive B. burgdorferi s. I IgM and/or IgG antibodies by ELISA enzyme immunoassays.

The Ig $\mathrm{G}$ antibodies to Lyme Borreliosis pathogens were detected more frequently -78.1 versus $21.9 \%, p<0.05$, while to tick-borne relapsing fever pathogens only in 12.3 versus $85.9 \%(p<0.05)$ of cases. B. burgdorferi s. I. IgG-antibodies were detected more frequently compared to $B$. hermsii and B. miyamotoi IgG-antibodies (78.1 versus $12.3 \%, p<0.05$ ). Forestry workers which were positive to antibodies to both Lyme borreliosis and tick-borne relapsing fever, noticed earlier beginning of tick-bites' season (March-October). They manifested intoxication syndrome and musculoskeletal damage more frequently compared to persons which were positive only to B. burgdorferi s. I. antibodies.

Key words: Lyme borreliosis; tick-borne relapsing fever; diagnostics; ELISA; immunoblot; questionnaire; forestry workers.

\section{Відомості про авторів:}

Шкільна Марія Іванівна - к. мед. н, доцент кафредри інфекційних хвороб з епідеміологією, шкірними та венеричними хворобами ТНМУ імені І.Я. Горбачевського; e-mail: shkilnami@tdmu.edu.ua

ORCID iD: https://orcid.org/0000-0002-2689-6349

Джотсна Шах - директор клінічної лабораторії «IGeneX Inc.» (Мілпітас, Каліфрорнія, США); e-mail: jshah@igenex.com; ORCID iD: https://orcid.org/0000-0001-9890-366X 
Андрейчин Михайло Антонович - д. мед. н., професор, академік НАМН України, завідувач кафедри інфекційних хвороб з епідеміологією, шкірними та венеричними хворобами ТНМУ імені І.Я. Горбачевського; e-mail: andreychyn@ tdmu.edu.ua

ORCID iD: https://orcid.org/0000-0003-0154-730X

Iріс Круз - менеджер клінічної лабораторії «IGeneX Inc.» (Мілпітас, Каліфорнія, США); e-mail: icruz@igenex.com

Івахів Олег Любомирович - к. мед. н., доцент кафредри інсекційних хвороб з епідеміологією, шкірними та венеричними хворобами ТНМУ імені І.Я. Горбачевського; e-mail: olivakhiv@ukr.net

ORCID iD: https://orcid.org/0000-0003-1917-1814

Корда Михайло Михайлович - д. мед. н., професор, ректор ТНМУ імені І.Я. Горбачевського; e-mail: korda@tdmu. edu.ua

ORCID iD: https://orcid.org/0000-0002-6066-5165

Кліщ Іван Миколайович - д. біол. н., профресор, проректор з наукової роботи ТНМУ імені І.Я. Горбачевського; e-mail: klishch@tdmu.edu.ua

ORCID iD: https://orcid.org/0000-0001-6226-4296

Запорожан Степан Йосипович - д. мед. н., професор, проректор $з$ науково-педагогічної та лікувальної роботи ТНМУ імені І.Я. Горбачевського; e-mail: zaporozhan@tdmu. edu.ua

ORCID iD: https://orcid.org/0000-0002-4038-2010

\section{Information about the authors:}

Shkilna M.I. - PhD, Associate Professor of the Department of Infectious Diseases and Epidemiology, Dermatology and Venerelogy, I. Horbachevsky Ternopil National Medical University; e-mail: shkilnami@tdmu.edu.ua

ORCID iD: https://orcid.org/0000-0002-2689-6349
Shah J. - Clinical Laboratory Director, "IGeneX Inc." (Milpitas, California, USA); e-mail: jshah@igenex.com; ORCID iD: https://orcid.org/0000-0001-9890-366X

Andreychyn M.A. - MD, Professor, Academician of the National Academy of Medical Sciences of Ukraine, Chief of theDepartment of Infectious Diseases and Epidemiology, Dermatology and Venerelogy, I. Horbachevsky Ternopil National Medical University; e-mail: andreychyn@tdmu.edu.ua ORCID iD: https://orcid.org/0000-0003-0154-730X

Cruz Iris - Clinical Laboratory Manager, "IGeneX Inc." (Milpitas, California, USA); e-mail: icruz@igenex.com Ivakhiv O.L. - PhD, Associate Professor of the Department of Infectious Diseases with Epidemiology, Dermatology and Venerelogy, I. Horbachevsky Ternopil National Medical University; e-mail: olivakhiv@ukr.net ORCID iD: https://orcid.org/0000-0003-1917-1814 Korda M.M. - MD, Professor, Rector, I. Horbachevsky Ternopil National Medical University; e-mail: korda@tdmu.edu.ua ORCID iD: https://orcid.org/0000-0002-6066-5165 Klishch I.M. - DS (Biology), Professor, Vice-rector for Scientifc Work, I. Horbachevsky Ternopil National Medical University; e-mail: klishch@tdmu.edu.ua ORCID iD: https://orcid.org/0000-0001-6226-4296 Zaporozhan S.Y. - MD, Professor, Vice-rector for Academic and Clinical Work, I. Horbachevsky Ternopil National Medical University; e-mail: zaporozhan@tdmu.edu.ua ORCID iD: https://orcid.org/0000-0002-4038-2010

Конорлікт інтересів: немає.

Authors have no conflict of interest to declare.

Отримано 23.05.2020 р. 